\title{
ACCESS TO MORTGAGE CREDIT AND HOUSING PRICE DYNAMICS
}

\author{
Eddie C. M. HUI a,*, Ivan M. H. NG ${ }^{\text {a }}$ \\ ${ }^{a}$ Department of Building and Real Estate, The Hong Kong Polytechnic University, Hung Hom, Kowloon, \\ Hong Kong, China
}

Received 18 February 2014; accepted 14 January 2015

\begin{abstract}
In real estate studies, arguably the most important topic revolves around what actually affect the price of properties. In addition to various macroeconomic factors, the mortgage industry is also believed to play a major role. Nonetheless, despite its profound implications on the banking sector, the property market, and the economy as a whole, there is no consensus as to the relationship between property price and bank mortgage lending. In light of this, this paper aims to investigate the relationship between property price and mortgage lending, along with other macroeconomic variables, in two housing sub-markets of Hong Kong (i.e. the mass housing market and the luxury housing market). The findings illustrate that one-way directional relationships are discovered 1) from mass housing price to mortgage lending; 2) from luxury housing price to mortgage lending; and 3) from mass housing price to luxury housing price. Macroeconomic factors such as GDP, inflation rate, and interest rate are also found to play a major role in influencing the prices of both property markets and the amount of outstanding mortgage loans. Implications based upon these findings are also discussed.
\end{abstract}

KEYWORDS: Mortgage lending; Property price; Mass residential market; Luxury residential market; Hong Kong

SUPPLEMENTARY MATERIAL associated with this article can be found, in the online version, at doi:10.3846/1648715X.2015.1103802

\section{INTRODUCTION}

Since the aftermath of the Asian Financial Crisis of the late 1990s, Hong Kong's real estate market has rebounded from the impact of economic downturn and property price has reached unprecedented levels, especially in the past 2 years ${ }^{1}$. The potential reasons behind such a development are: 1) low borrowing cost; and 2) inflow of foreign capital (including Mainland China). Both reasons help boost housing demand (and housing price) in Hong Kong, with the first of which also boosting the demand for mortgage loans. Nonetheless, as banks also become increasingly engaged in the mortgage

\footnotetext{
1 The recent U.S. subprime crisis and the following financial tsunami, though leading to economic problems around the globe especially in the U.S. and in many European nations, only managed to halt the rise of Hong Kong's property price for less than 9 months, as suggested by statistics compiled by the Rating and Valuation Department. In fact, the current price level of residential properties is even higher than that prior to the outbreak of the Asian Financial Crisis back in 1997.

* Corresponding author. E-mail: bscmhui@polyu.edu.hk
}

financing business due to higher demand for mortgage loans, they in turn act like an "accelerator" in the run-up of property prices.

This provides an interesting dynamic when it comes to property price and bank lending in the form of mortgage loans, and their interactions have profound implications on not just the banking sector and the property market, but the economy as a whole. For instance, according to international studies (IMF 2000; BIS 2001), bank capital and profitability could be profoundly affected by the downturn in economic activity and the collapse in property prices. Therefore, the interactions between the property market and bank credit is an important, and broad, issue of concern to policymakers, regulators, academics, and investors alike.

In light of this, this study purports to investigate the relationships between mortgage lending and property price in Hong Kong. There are a number of reasons behind the selection of the Hong Kong market for study. First, as will be shown in the following literature review section, the majority of previous studies in this regard have primarily 
focused on their relationships during economic downturn, for instance during the Asian Financial Crisis. Second, most of these investigations have assumed a one-way directional relationship between property price and bank lending, while, outside of a handful of studies, the possible twoway interactions between the two have been usually overlooked. Third, most previous studies have investigated the housing market as a whole, even though the impact of the same macroeconomic and monetary factors could yield very different results for different housing sub-markets, for instance the mass residential property market and the luxury residential property market. Lastly, due to the linked exchange rate system, under which the Hong Kong Dollar is pegged to the U.S. Dollar, Hong Kong's monetary policies are much more constrained than those in nations under a floating exchange rate system, in that the connection with the U.S. Dollar has essentially stripped the Hong Kong government the authority to adjust both money supply and interest rates in response to market changes. A study of how such limitations affect the territory's residential property market (and the economy) would serve as a reference for the studying of other nations under similar financial arrangements.

Taking those conditions into consideration, this study investigates both housing sub-markets in Hong Kong in a period during which the housing market has been experiencing an upward trend. The findings are expected to give some insights, from a different perspective, as to the interactions between property price and banks' mortgage financing, and to contribute to existing literature in this regard.

The paper is organized as follows: After this introduction, previous studies with regard to the relationship between property price and bank lending are to be reviewed. Following the literature review section, Section 3 articulates the methodologies deployed for this investigation and the data samples. Then, the research findings are to be presented and discussed in Section 4. The last section concludes the study.

\section{LITERATURE REVIEW}

\subsection{The importance of studying the relationship between property price and bank lending}

Studying the causal relationship between bank lending and property price is critical not only to financial institutions, but also to government agen- cies responsible for fiscal and monetary policymaking. Real estate is by far the largest (i.e., most costly) asset for the vast majority of households, which highly depends on the availability, cost, and flexibility of debt financing from financial institutions such as banks (Tsatsaronis, Zhu 2004). This not only is a major factor in the determination of housing demand (and thus housing price dynamics), but also of the amount of mortgage loans banks are willing to lend.

By having a better understanding of the relationship between these two factors, housing price movements and changes in the level of household borrowing could be forecasted more accurately, which helps market practitioners such as banks and investors alike to make more effective decisions in investment and in risk management (Liang, Cao 2007). Besides, the knowledge regarding the linkages between property price and bank lending is important for fiscal- and monetary policymaking, for the interaction between the two could very well render the financial sector more susceptible to shocks by augmenting boom-bust cycles in the economy (Oikarinen 2009; Goodhart, Hofmann 2007). According to Goodhart and Hofmann (2007), future banking sector distress could be detected through the deviations of housing price and bank credit from their respective long-run trends, which is something policymakers must know prior to devising appropriate policy initiatives in response.

\subsection{Interaction between property price and bank credit}

\section{One-way causality from property price to bank lending}

As to how property price and bank lending interact with each other, one school of thought is that changes in property price affect the amount of mortgage loans offered by banks through four different channels ${ }^{2}$. The first is that, due to financial market imperfections, more specifically asymmetric information in the credit market, households and firms may be borrowing constrained which induces adverse selection and moral hazard issues. As a result, banks would only proffer mortgage loans should a collateral, which is the property itself, be provided. In other words, these households' and firms' borrowing capacity becomes a function of the net worth of this collateral (or price of the asset) (Hofmann

$\overline{{ }^{2} \text { However, }}$ it is argued by Hofmann (2004) that, higher property prices are likely to be followed by higher property rents. In response, renters may reduce consumption and borrowing. 
2003; Goodhart, Hofmann 2003; Aoki et al. 2004; Iacoviello 2004, 2005; Bernanke, Gertler 1995; Kiyotaki, Moore 1997). Secondly, by affecting consumers' perceived lifetime wealth, property price adjustments shape their spending and borrowing plans in order to smooth consumption over households' life cycle, the latter of which inevitably influences credit demand (Hofmann 2003; Goodhart, Hofmann 2003). Thirdly, property prices influence the bank capital position and lending capacity through the value of 1) their own real estate assets; and 2) mortgage loans secured by others' properties (Hofmann 2003; Oikarinen 2009). Lastly, property prices may affect demand for credit by stimulating economic activities (Hofmann 2004).

There are numerous studies which provide empirical support to such a notion. For example, it is found by Goodhart (1995) that property prices affect the growth in bank lending in the U.S. ${ }^{3}$ Goodhart and Hofmann (2003), deploying a VAR impulse response analysis, investigate this issue of twelve different countries, including the G7, Sweden, Norway, Finland, along with Hong Kong and Singapore, and the findings are that innovations to property prices significantly influence bank lending in the majority of these nations.

Gerlach and Peng (2003, 2005), in two separate studies, investigate the relationship between property price and bank lending in Hong Kong, based on standard regression techniques, and find that the direction of causality goes from property price to bank lending, both in the short-run and in the longrun. However, two other studies conducted by Hofmann (2003; 2004) reach slightly different results. In a study of 20 countries using both time series and panel data techniques, Hofmann (2003) finds that property prices appear to cause bank lending only in the long-run. He goes further and concludes that property price cycles, as a reflection of changing beliefs with respect to future economic situations, drive credit cycles, not the other way around. His other investigation in this regard involving 16 industrialized countries (2004), based upon a cointegrating VAR, is also only able to find a long-run causality from property price to bank lending.

\section{One-way causality from bank lending to property price}

Another school of thought, interestingly also based on asymmetric information, suggests that it is instead the supply of bank loans which influence demand for housing (hence property price) via dif-

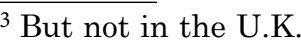

ferent liquidity effects, particularly when households are borrowing-constrained (for instance, Stein 1995; Ortalo-Magné, Rady 2006; Jin, Zeng 2004; Barakova et al. 2003; Yamashita 2007). As mentioned in earlier paragraphs, faced with asymmetric information, banks are likely to 1) screen households cautiously and 2) require the borrower to pledge a collateral in order to minimize the risks incurred due to moral hazard behaviour. This is particularly the case in a higher interest rate environment, in which the net worth of households attenuates while their interest payments become higher. Under these conditions, the consequences of asymmetric information worsen, leading to lower supply of bank loans to households (De Greef, De Haas 2000). Also, according to Hofmann (2003), higher availability of bank credit may result in lower interest rates and stimulate economic activity, be in current or future. Under this circumstance, property prices may rise due to higher expected returns on real estate and a lower discount rate ${ }^{4}$. In addition, higher availability of bank credit may generate higher housing demand as the supply of housing is relatively fixed in the short-run (also see Park et al. 2010).

A variety of previous studies have provided empirical support to this school of thought. Collyns' and Senhadji's (2001) study of four East Asian nations, namely Hong Kong, Korea, Singapore, and Thailand discovers that credit growth is significant in determining residential property prices, and the authors conclude that bank lending is one of the major contributing factor to the formation of real estate bubble in Asia preceding the Asian Financial Crisis of the late 1990s. Similarly, it is opined by Koh et al. (2005) that "financial intermediaries' under-pricing of the put option imbedded in non-recourse mortgage loans" could very well have been a potential cause for the Asian property price run-up and subsequent collapse in the late 1990s. Liang and Cao (2007), utilizing a high dimensional autoregressive distributed lag (ARDL) framework, find a one-way causality from bank lending to property prices in Mainland China between 1999:1 and 2006:2. The study by Park et al. (2010) on the Korean residential and credit markets show that oneway causality from bank lending to property price is more prominent in the short-run in 'cold' (as in, non-targeted, comparatively unpopular) markets, while the same kind of causality is stronger in the

\footnotetext{
$\overline{4}$ The price of property, as an asset, can be seen as the sum of the discounted future stream of property returns.
} 
'hot' market (i.e., targeted, popular areas such as Kangnam) in the long-run.

As for studies on western nations, Wheaton and Negachev (2006) comment that the price run-up of the U.S. housing market was partly the result of an emerging active sub-prime credit market, which has helped achieve the highest national home ownership rate in history. In addition, it is concluded by Ahearne et al. (2005) that a period of easing monetary policy usually precedes house price booms.

\section{Two-way causality between property price and bank lending}

Nonetheless, it is argued by Hofmann (2003) that these two schools of thought only assume one-way causality between property price and bank lending, while overlooking the potential two-way causality between them. According to Hofmann (2003), such type of causality may result in mutually-reinforcing cycles in the credit market and in the property market. For instance, higher property prices, as a result of optimistic expectations as to future economic performance, enhance the capacity for firms and households to borrow as the value of collateral climbs. The extra credit obtained from banks could then be used on other property investments, in turn causing property prices to rise even further.

As for studies supporting this notion, Hofmann's (2001) study of 16 industrialized countries shows that a significant two-way causality relationship exists between bank lending and property price. Similar results have also been found in Hofmann (2003), Davis and Zhu (2004), and Kim (2004). Besides, there are some other European studies in which similar findings have been yielded. For instance, a study by De Greef and De Haas (2000) in the Netherlands shows that property prices were affected by bank lending criteria changes even when variables such as disposable household income, mort- gage interest rate, demographic developments and the housing stock are controlled. Another study by Fitzpatrick and McQuinn (2007) on the Irish property and credit markets, using various econometric approaches, also find similar mutually reinforcing relationship between these two factors. In addition, not only such a two-way causal relationship between bank lending and property price has been found by Oikarinen (2009) in his study of the Finnish markets, he concludes that housing prices influence both housing loans and consumption loans substantially, the former of which in turn plays a critical role in shaping property prices.

\section{METHODOLOGY AND DATA}

Prior to a presentation of the methods deployed for this study, the Vector autoregression model (VAR), which provides the basis for the impulse response and variance decomposition analyses, is discussed first.

\subsection{The Vector autoregression (VAR) model}

The vector autoregression (VAR) model is generally used for analyzing the dynamic impact of random disturbances on a system of variables, and forecasting systems of interrelated time series. The VAR approach sidesteps the need for structural modeling to treat every variable as endogenous in the system as a function of the lagged values of all endogenous variables in the system, while all the variables in a VAR system are treated symmetrically.

The VAR system is expressed in the form of Equation (1) below:

$$
y_{t}=\sum_{i=1}^{n} A_{i} y_{t-i}+\sum_{i=1}^{n} B_{i} x_{t-i}+\ldots \ldots .+\varepsilon_{t}
$$

$$
\left(\begin{array}{c}
y_{t}^{1} \\
y_{t}^{2} \\
y_{t}^{3} \\
\cdots \\
y_{t}^{k}
\end{array}\right)=\left(\begin{array}{ccc}
A_{11} & \cdots & A_{1 k} \\
\vdots & \ddots & \vdots \\
A_{k 1} & \cdots & A_{k k}
\end{array}\right)\left(\begin{array}{l}
\sum_{i=1}^{n} y_{t-i}^{1} \\
\sum_{i=1}^{n} y_{t-i}^{2} \\
\sum_{i=1}^{n} y_{t-i}^{3} \\
\cdots \\
\sum_{i=1}^{n} y_{t-i}^{k}
\end{array}\right)+\ldots+\left(\begin{array}{ccc}
B_{11}^{n} & \cdots & B_{1 k}^{n} \\
\vdots & \ddots & \vdots \\
B_{k 1}^{n} & \cdots & B_{k k}^{n}
\end{array}\right)\left(\begin{array}{l}
\sum_{i=1}^{n} x_{t-i}^{1} \\
\sum_{i=1}^{n} x_{t-i}^{2} \\
\sum_{i=1}^{n} x_{t-i}^{3} \\
\cdots \\
\sum_{i=1}^{n} x_{t-i}^{k} \\
e^{n}
\end{array}\right)+\left(\begin{array}{l}
e_{1 t} \\
e_{2 t} \\
e_{3 t} \\
\cdots \\
e_{k t}
\end{array}\right)
$$


in which is the number of variables to be considered in the system while is the number of lags of these variables. are the $x$ matrices of coefficients to be estimated, and is a vector of innovations that may be contemporaneously correlated but are uncorrelated with their own lagged values and with lagged values of the endogenous variables on the right-hand side of Equation (1).

\subsection{Impulse response and variance decomposition analyses}

After carrying out the VAR model, the impulse response analysis is then used to evaluate the effectiveness of changes in a factor, for example increasing interest rate, on specific dependent variables. More specifically, an impulse response function provides a different method in depicting the system dynamics, by tracing the effects of the shock of an endogenous variable on the variables in the VAR model. An impulse response function describes how one or more endogenous variables reacts over time to exogenous impulses or shocks, by tracing the effect of a one standard deviation shock to one of the innovations on the current and future values in a VAR system (Sims et al. 1990).

In addition, in order to further explore the source of variability of different variables, variance decomposition is used to complement the interpretation of the VAR model once the model has been fitted. It indicates the amount of information each variable contributes to other variables in the autoregression. It determines how much of the forecast error variance of the observed variable can be explained by the exogenous shocks in other variables, in the sense that it helps understand the relative importance of each random innovation in affecting the model variables and decompose which factor(s) is/are better predictors.

\subsection{The data}

In this study, monthly data of different categories, obtained from various Hong Kong government agencies for the period January 2004 - March 2012 , are deployed for the analysis. The rationales for picking this time span are data availability and the ample evidence of economic cycle - the overall economy of Hong Kong started to recover in 2004 (in the aftermath of the Asian Financial Crisis of the late 1990s followed by the SARS epidemic of 2003), then went down dramatically during the financial crisis of 2007-2008 only to rebound again during 2009-2012. The domestic property market generally followed the movements of the economy during the period.
The main variables include: 1) private domestic-price indices for the mass residential market and for the luxury residential market as compiled by the Rating and Valuation Department; and 2) the amount of mortgage loans collected from the Hong Kong Monetary Authority (HKMA). In addition to these two factors, a set of control variables namely, GDP, inflation rate, interest rate, and money supply, are included as well. The currency of variables is denoted in Hong Kong dollar unless mentioned otherwise.

Prior to further investigations, the selected data samples are first tested for their stationarity, and it is found that all the selected variables (except GDP) require first differencing in order to be stationary, and GDP needs to be second-differenced in order to be stationary.

\section{THE FINDINGS}

\subsection{Results of the VAR model}

Prior to running the VAR model, the optimal amount of lags in the VAR model is to be determined first. Generally, the lowest Akiake Information Criterion (AIC) \& Schwarz Criterion (SC) represent the optimal lag structure of the VAR. In our model, with the inclusion of lagged variables up to 11 lags yields the lowest AIC \& SC (Table 1), and the results of this VAR model are included in Supplementary Appendix 1.

Table 1. Akaike information criterion and Schwarz criterion of the VAR model

\begin{tabular}{lll}
\hline $\begin{array}{l}\text { Number of } \\
\text { lags }\end{array}$ & $\begin{array}{l}\text { Akaike information } \\
\text { criterion }\end{array}$ & Schwarz criterion \\
\hline 2 & 54.87 & 57.69 \\
3 & 55.23 & 59.40 \\
4 & 55.44 & 60.96 \\
5 & 55.55 & 62.46 \\
6 & 54.69 & 63.00 \\
7 & 54.50 & 64.22 \\
8 & 53.49 & 64.65 \\
9 & 51.24 & 63.85 \\
10 & 50.09 & 64.18 \\
11 & 41.00 & 56.59 \\
\hline
\end{tabular}

As for the findings of the VAR model itself, numerous significant (lagged) variables (within 5\% significance level) are identified for all selected variables. For mass housing price (PPIA), two variables, namely mass housing price (with an 8-month lag) and luxury housing price (PPIB; with a 3-month lag) are found to be statistically significant. On the other hand, luxury market price (with a 3-month 
lag) and inflation rate (CCPI; with a 4-month lag) are significant in explaining PPIB. As for residential mortgage loans, four sets of variables are found to be significant, such as PPIA (3- and 11-month lags), PPIB (4-month lag), GDP (2- and 11-month lags), and CCPI (2- and 6-month lags).

With regard to other variables included in the model, GDP can be largely explained by its own lagged values (3-, 6-, and 9-month lags) as well as by CCPI (8-month lag). Meanwhile, CCPI itself is subject to changes in PPIA (10-month lag) and CCPI itself (1-, 2-, 3-, and 11-month lags). Additionally, lagged money supply (8-month lag) is significant in explaining interest rate adjustments, while PPIA (6- and 10-month lags), PPIB (3- and 4-month lags), CCPI (7-month lag), and interest rate (8- and 11-month lags) are significant in explaining money supply.

Nonetheless, the VAR model itself only shows the separate impacts of lagged values of selected variables, while unable to inform us how these lagged variables, when combined together, influ- ence the dependent variables over time. The Impulse Response analysis and the Variance Decomposition analysis, therefore, are deployed for this purpose; and the findings are presented in the following sections.

\subsection{Generalized impulse response analysis}

\section{Property prices}

The results obtained from the impulse and accumulated response analysis for prices of mass residential properties are shown in Figures 1 and 2 . With regard to the impulse response of mass housing price to the selected variables, the two types of stocks which trigger the largest response are past property price in the mass housing market and luxury housing price. As for the other macroeconomic factors, GDP appears to incur the largest response from the mass housing market, followed by interest rate and inflation rate. Comparatively speaking, the responses from shocks in mortgage loans and money supply are not as remarkable.
Response of D(PPIA) to D(PPIA)

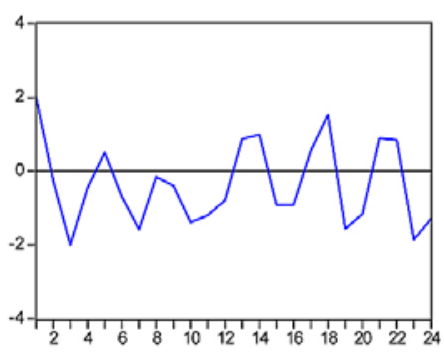

Response of D(PPIA) to $D(G D P, 2)$

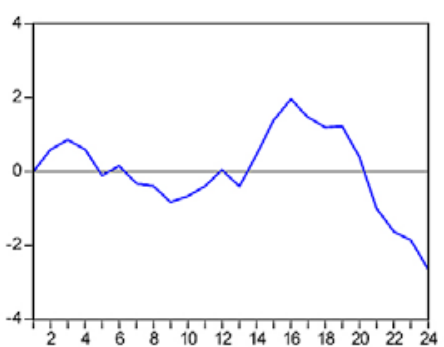

Response of D(PPIA) to D(MS)

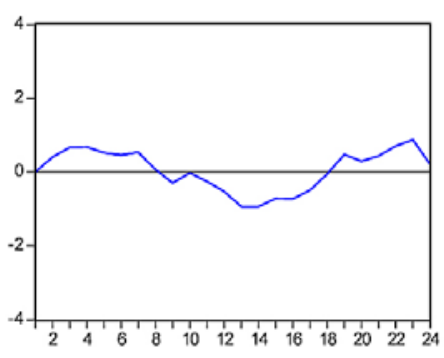

Response to CholeskyOne S.D. Innovations
Response of $\mathrm{D}(\mathrm{PPIA})$ to $\mathrm{D}(\mathrm{PPIB})$

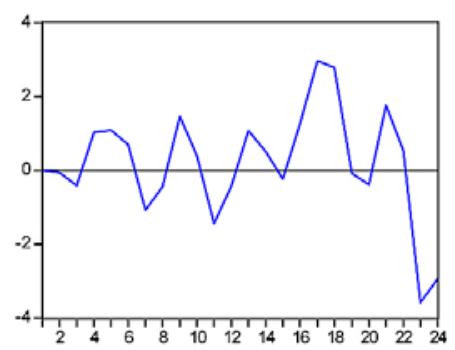

Response of D(PPIA) to $\mathrm{D}(\mathrm{CCPI})$

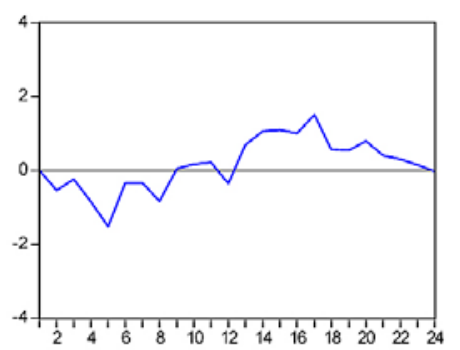

Response of D(PPIA) to D(LOAN)

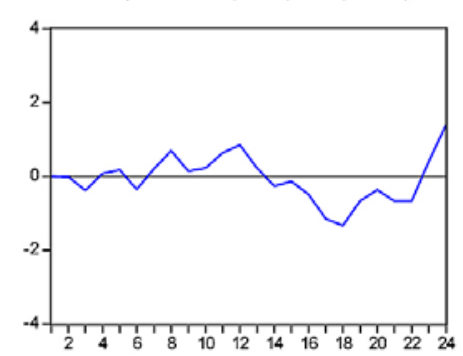

Response of D(PPIA) to D(YIELD)

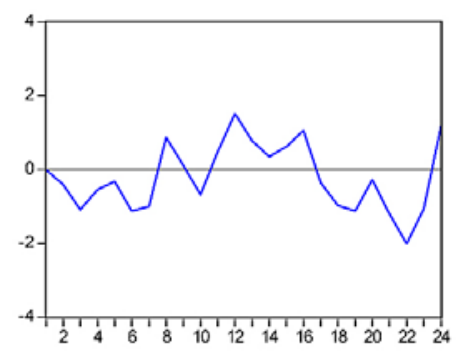

Fig. 1. Impulse response of mass residential prices to explanatory variables 
Accumulated Response to Cholesky One S.D. Innovations

Accumulated Response of D(PPIA) to D(PPIA)

Accumulated Response of D(PPIA) to D(PPIB)

Accumulated Response of $\mathrm{D}$ (PPIA) to $\mathrm{D}(\mathrm{LOAN})$
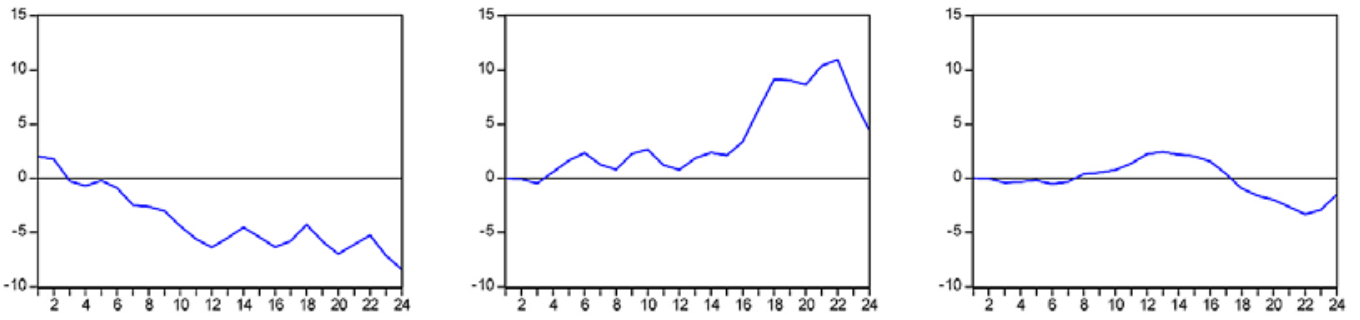

Accumulated Response of D(PPIA) to D(GDP,2)

Accumulated Response of $\mathrm{D}$ (PPIA) to $\mathrm{D}(\mathrm{CCPI})$

Accumulated Response of D(PPIA) to D(YIELD)
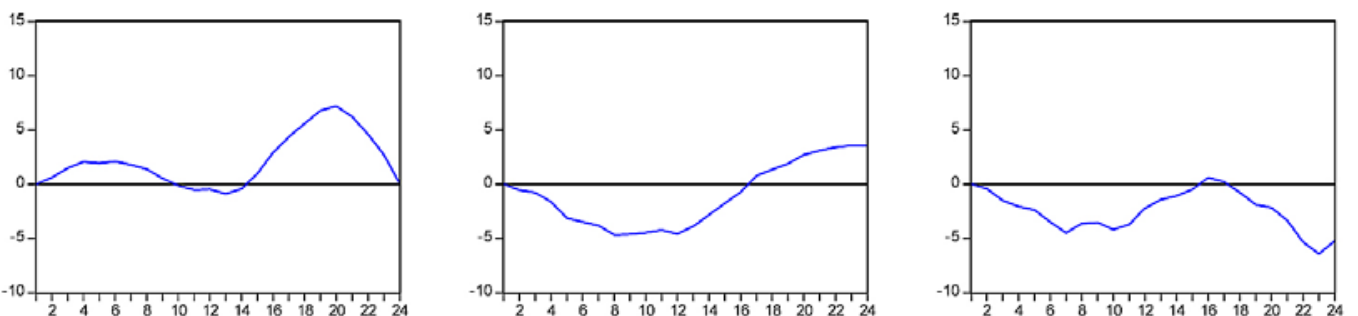

Accumulated Response of $\mathrm{D}(\mathrm{PPIA})$ to $\mathrm{D}(\mathrm{MS})$

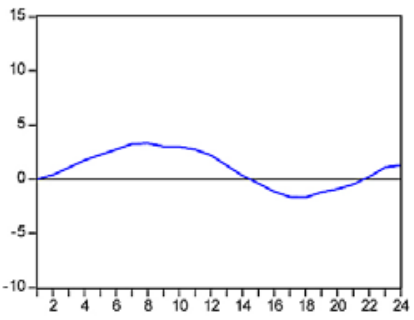

Fig. 2. Accumulated response of mass residential prices to explanatory variables

Accumulatively, mass residential property price responds negatively to past mass residential property price changes, yet positively to changes in luxury housing price. Of the other selected variables, it is found that mass housing price generally responds positively to adjustments in money supply (particularly in the shorter-run) and in GDP (especially in the long-run), yet negatively to changes in inflation (only in the shorter-run but not in the long-run) and in interest rate. Interestingly, the dynamics of the mortgage loan market does not appear to have a very significant impact on the adjustments in housing price in the mass residential market.

The situation is largely similar for the luxury residential market (Figs 3 and 4). The prices of the two housing markets are found to trigger vigorous responses from the luxury housing market. In addition, larger responses (as compared to the mass housing market) are identified towards shocks in
GDP, inflation rate, and interest rate, and to a lesser extent, shocks in mortgage loans and money supply.

As for the accumulative responses towards the selected variables, in addition to its previous adjustments, shocks of five factors are shown to be positive and significant in luxury housing price, which are the price of the mass residential market, inflation rate, GDP, money supply, and interest rate. It appears that, besides its past movements, the price level of the luxury housing market responds the most vigorously to that of the mass housing market (negative), followed by shocks from GDP (largely positive) and inflation rate (negative in the short- to middle-run and positive in the longer-run), and to a lesser extent, money supply (positive in general) and interest rate (generally negative). In comparison with the responses of mass housing price, it appears that the responses of luxury housing price to shocks of the selected variables are larger. 
Response to CholeskyOne S.D. Innovations

Response of D(PPIB) to D(PPIA)

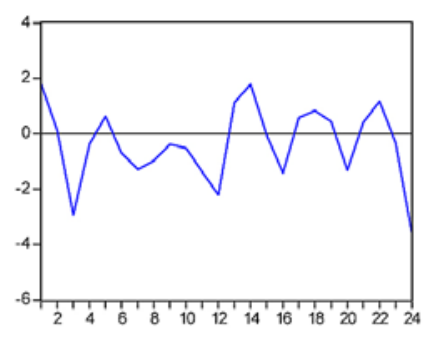

Response of $\mathrm{D}(\mathrm{PPIB})$ to $\mathrm{D}(\mathrm{GDP}, 2)$

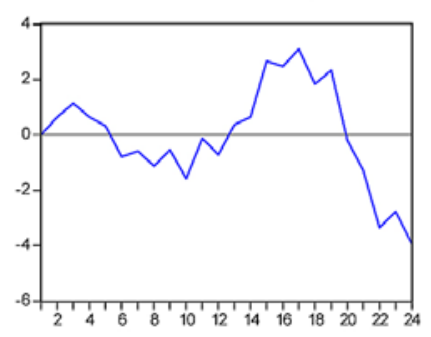

Response of D(PPIB) to D(MS)

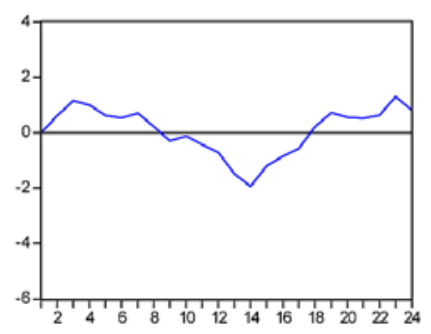

Response of $D(P P I B)$ to $D(P P I B)$

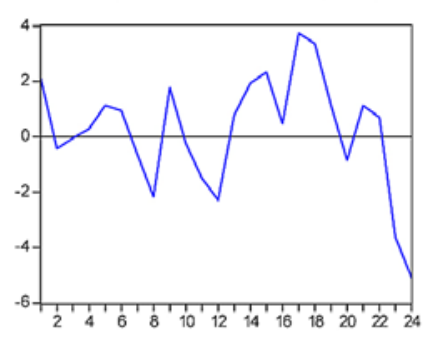

Response of $\mathrm{D}(\mathrm{PPIB})$ to $\mathrm{D}(\mathrm{CCPI})$

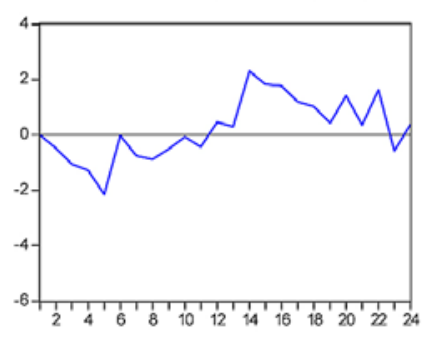

Response of D(PPIB) to D(LOAN)

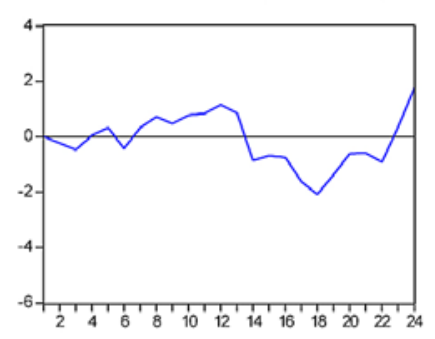

Response of D(PPIB) to D(YIELD)

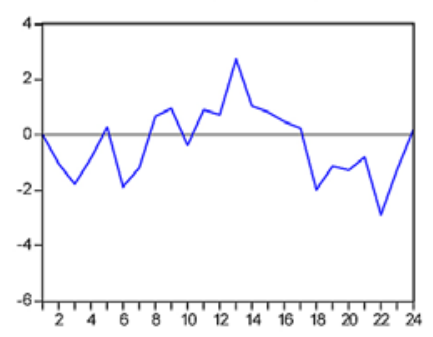

Fig. 3. Impulse response of luxury residential prices to explanatory variables

Accumulated Response to Cholesky One S.D. Innovations

Accumulated Response of D(PPIB) to D(PPIA)
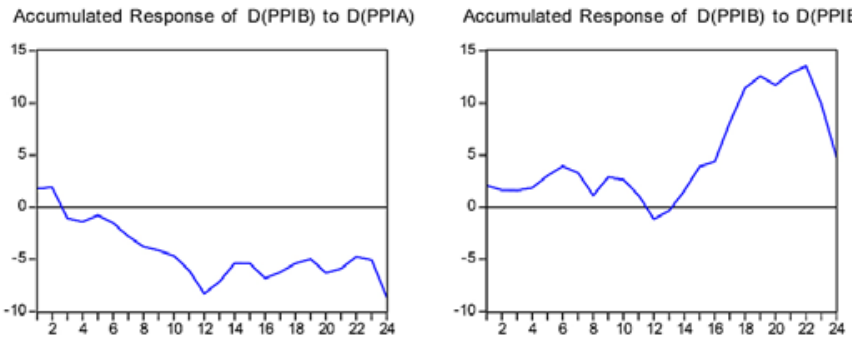

Accumulated Response of $\mathrm{D}(\mathrm{PPIB})$ to $\mathrm{D}$ (LOAN)

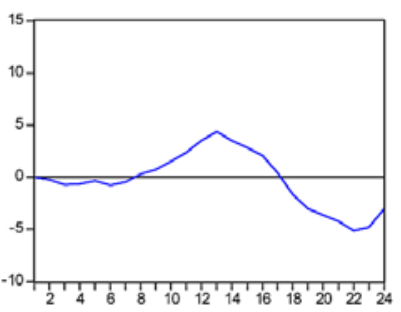

Accumulated Response of D(PPIB) to D(GDP.2)

Accumulated Response of $\mathrm{D}$ (PPIB) to $\mathrm{D}(\mathrm{CCPI})$

Accumulated Response of D(PPIB) to D(YIELD)
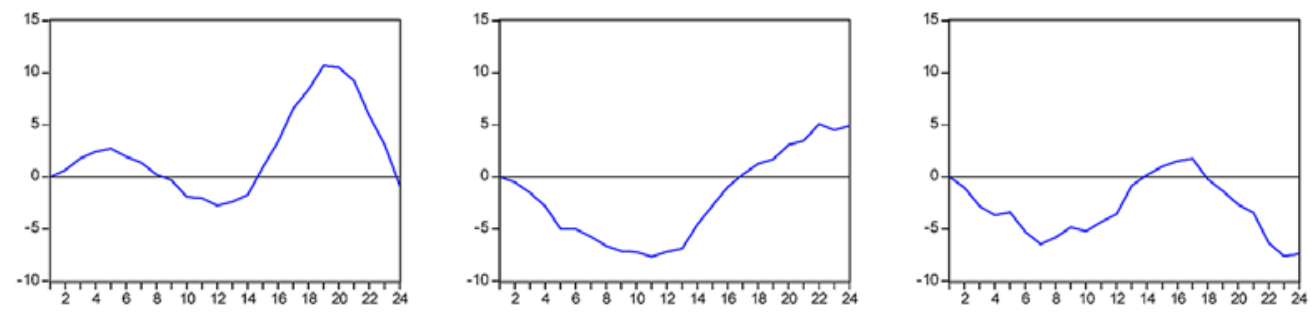

Accumulated Response of $D$ (PPIB) to $D$ (MS)

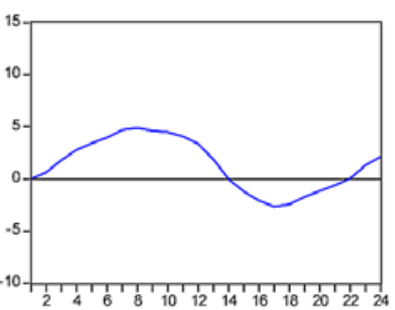

Fig. 4. Accumulated response of luxury residential prices to explanatory variables 


\section{Residential mortgage loans}

Concerning the impulse response of residential mortgage loans (Fig. 5), it is found that it reacts the most vigorously towards the prices of the two housing markets. Yet, comparatively speaking, the response to shocks in the mass residential market is more negative than that to shocks in the luxury housing market. Additionally, two other macroeconomic factors, namely interest rate and GDP, induce certain level of responses from residential mortgage loans. It should be noted that, both money supply and previous mortgage loans do not contribute much to the responses of mortgage loans.

As for the accumulated responses of residential mortgage loans to the selected variables (Fig. 6), some interesting themes have been identified. For instance, while mortgage loans respond positively to shocks in luxury housing price, the response to mass housing price, however, is negative. In addition to mass housing price, shocks in interest rate also trigger a generally negative response from residential mortgage loans. In comparison, shocks in other macroeconomic factors included in the model do not result in significant responses from bank mortgage leading, be they negative or positive.

\subsection{Variance decomposition analysis}

The impulse response analysis in the previous section quantifies the reaction of housing prices and residential loans to common exogenous shocks. Implications about the propagation mechanism between the residential markets and bank credit can be derived. Another method for the examination of the effects of disturbances on the endogenous variables is the forecast error variance decompositions. It separates the variation(s) in an endogenous variable into the component shocks to the VAR, thereby providing information about the relative importance of each innovation.

\section{Of mass residential property prices}

The results of the variance decomposition test, as shown in Figure 7, show that the primary contributions to the variation in mass residential market price, besides itself, are luxury property price

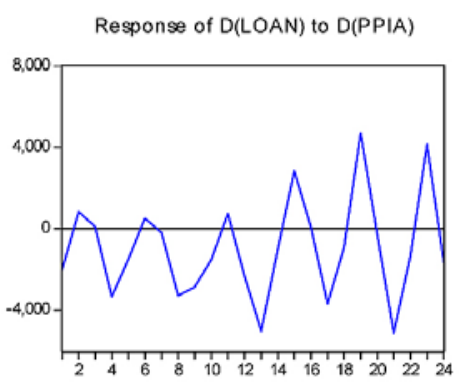

Response to Cholesky One S.D. Innovations
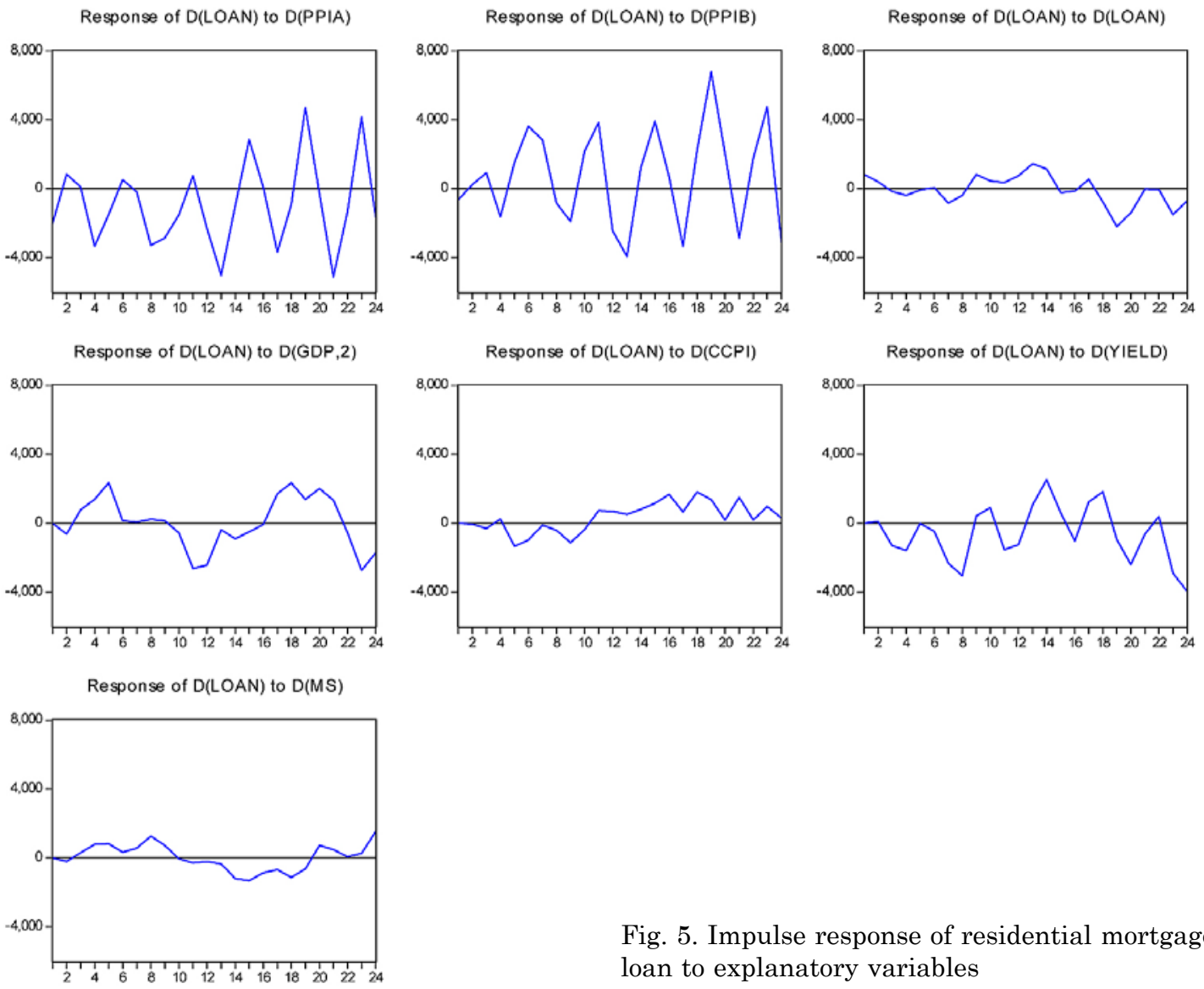

Fig. 5. Impulse response of residential mortgage loan to explanatory variables 


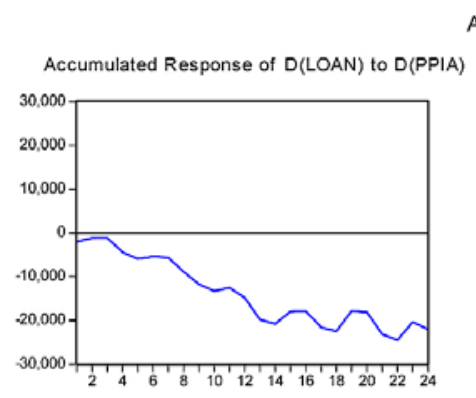

Accumulated Response to Cholesky One S.D. Innovations

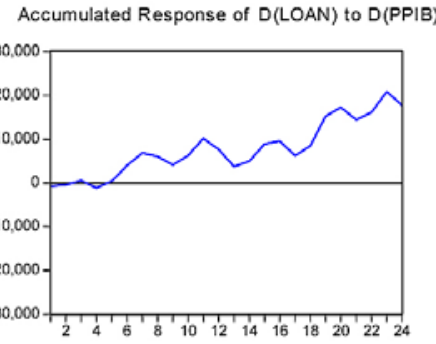

Accumulated Response of $D(L O A N)$ to $D(L O A N)$

Accumulated Response of $D(L O A N)$ to $D(G D P, 2)$

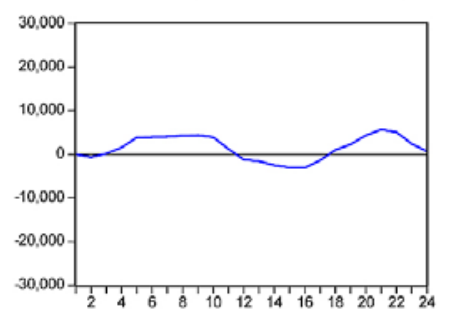

Accumulated Response of $D(L O A N)$ to $D(C C P I)$
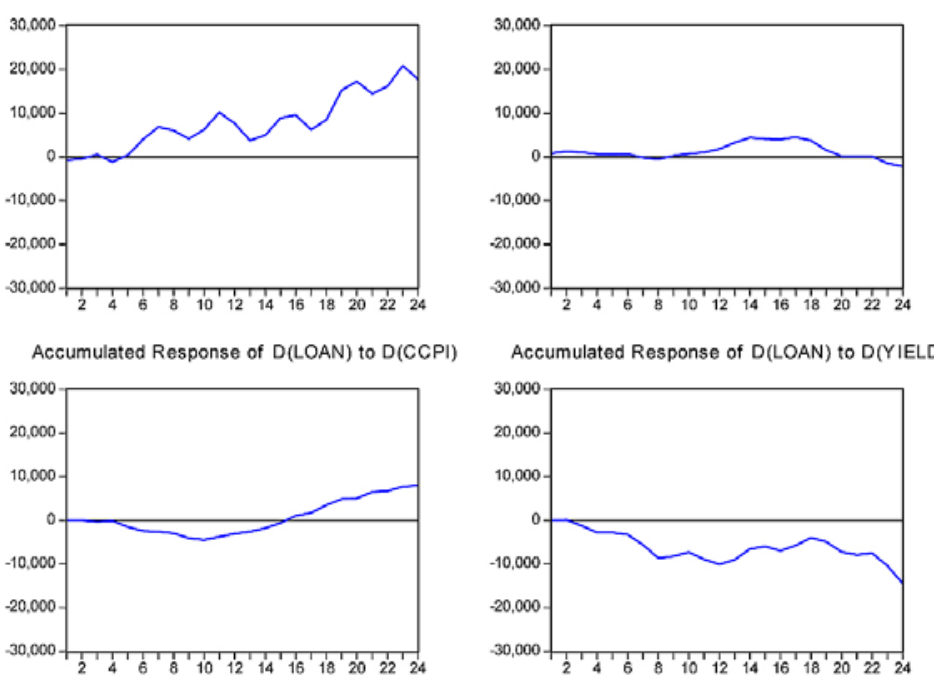

Accumulated Response of D(LOAN) to D(YIELD)

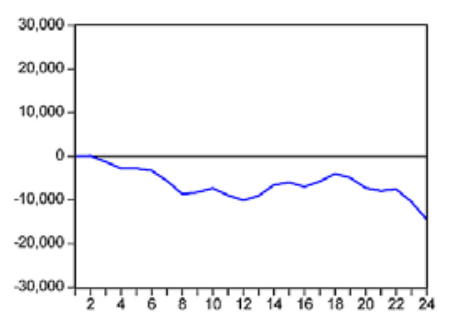

Accumulated Response of $\mathrm{D}(\mathrm{LOAN})$ to $\mathrm{D}(\mathrm{MS})$

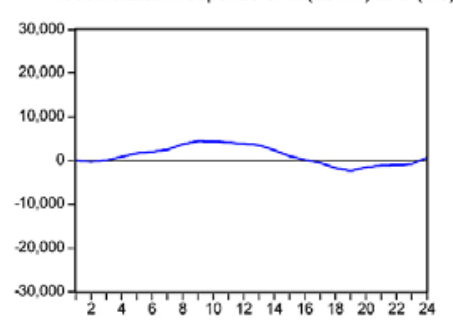

Fig. 6. Accumulated response of residential mortgage loan to explanatory variables

(close to $33 \%$ in the $24^{\text {th }}$ month), GDP (as much as $17 \%$ in the $24^{\text {th }}$ month), inflation rate $(17 \%$ in the $5^{\text {th }}$ month), and interest rate $\left(17 \%\right.$ in the $12^{\text {th }}$ month). It should be noted that, while the impact of GDP on the variance of property prices in the mass residential market appears in latter periods, those of inflation rate and of interest rate look to be more sustained throughout the period. Surprisingly, the impact of outstanding mortgage loan is negligible.
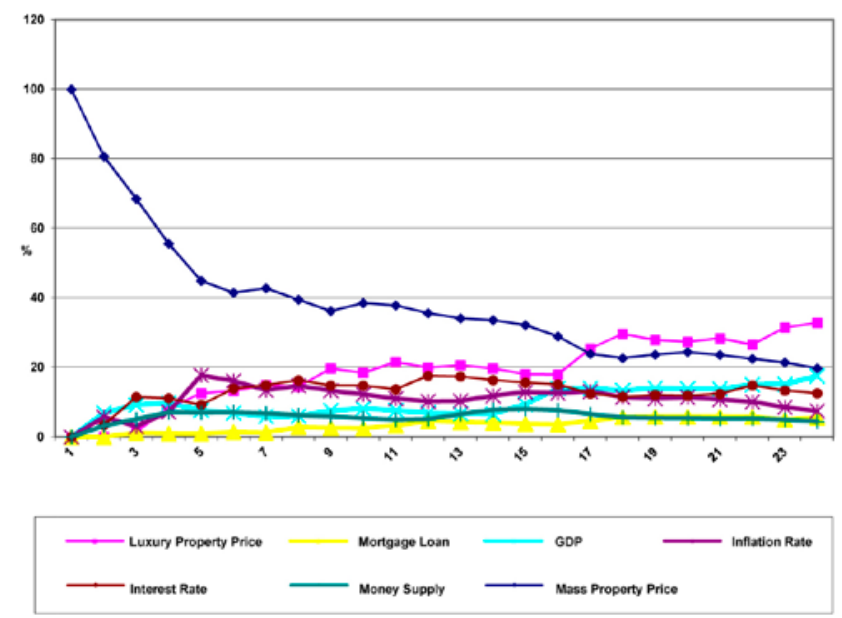

Fig. 7. Variance decomposition of mass residential price

\section{Of luxury residential property prices}

For the luxury residential property price (Fig. 8), its variance, within the first few months, is largely explained by its previous price and mass residential property price. Afterwards, these two factors explain approximately $40 \%$ of the variance of luxury housing price combined. Similar to mass housing price, three other selected variables are significant in explaining the variance of housing price in the luxury housing market, namely GDP (as much as $23 \%$ in the $24^{\text {th }}$ month), inflation rate (as much as $20 \%$ in the $5^{\text {th }}$ month), and interest rate (as much as $21 \%$ in the $7^{\text {th }}$ month). In addition, the impacts of outstanding mortgage loans and money supply, in comparison, are not as prominent.

\section{Of residential mortgage loans}

As for what affects the amount of residential mortgage loans the most, the findings (Fig. 9) show that price of mass residential properties, price of luxury residential properties, GDP, and interest rate are the major factors contributing to the variance of outstanding mortgage loans. Yet, money supply does not incur a significant effect on the amount of outstanding mortgage loan in the market. It should also be noted that, unlike the housing prices under study, the contributions of these significant factors 


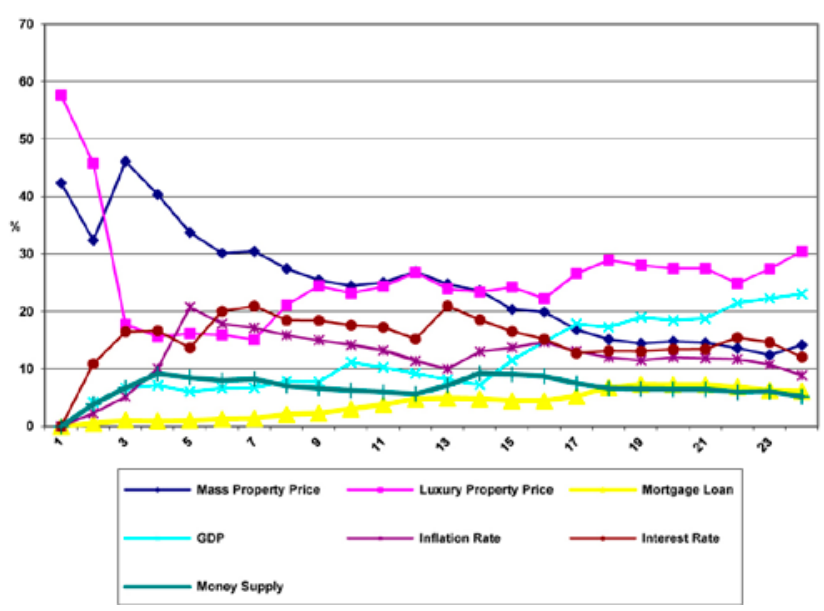

Fig. 8. Variance decomposition of luxury residential price

on explaining the variance of residential mortgage loans appear to be relatively consistent throughout the study period.

To sum up, the results proffer evidence as to the sources of co-movement(s) between various factors, particularly between mortgage loan and housing prices (both mass market and luxury market). Nevertheless, the impulse response analysis and the variance decomposition analysis are unable to inform us as to whether one-directional or two-direction relationship exists between the three key indicators in this study: mass housing price, luxury housing price, and residential mortgage loan. In light of this, the Granger Casualty test has been carried out. The results show that, at $10 \%$ significance level, the following causal relationships ${ }^{5}$ are found:

1) Mass housing price $\rightarrow$ Luxury housing price;

2) Mass housing price $\rightarrow$ Mortgage loans;

3) Luxury housing price $\rightarrow$ Mortgage loans

As shown above, the findings obtained from the Granger Causality tests indicate that in Hong Kong, only one-way directional causal relationships exist between the housing market and residential mortgage loans. While price adjustments in both the mass housing market and the luxury housing market are found to Granger-cause chang-

\footnotetext{
5 The other significant causal relationships among the selected variables are (see Supplementary Appendix 2):

- Mass housing price $\rightarrow$ Inflation rate;

- Luxury housing price $\rightarrow$ Inflation rate;

- GDP $\rightarrow$ Luxury housing price;

- GDP $\rightarrow$ Mortgage loans;

- Inflation rate $\rightarrow$ GDP;

- Money supply $\rightarrow$ GDP;

- Money supply $\rightarrow$ Interest rate;

- Money supply $\rightarrow$ Inflation rate; and

- Interest rate $\rightarrow$ Inflation rate.
}

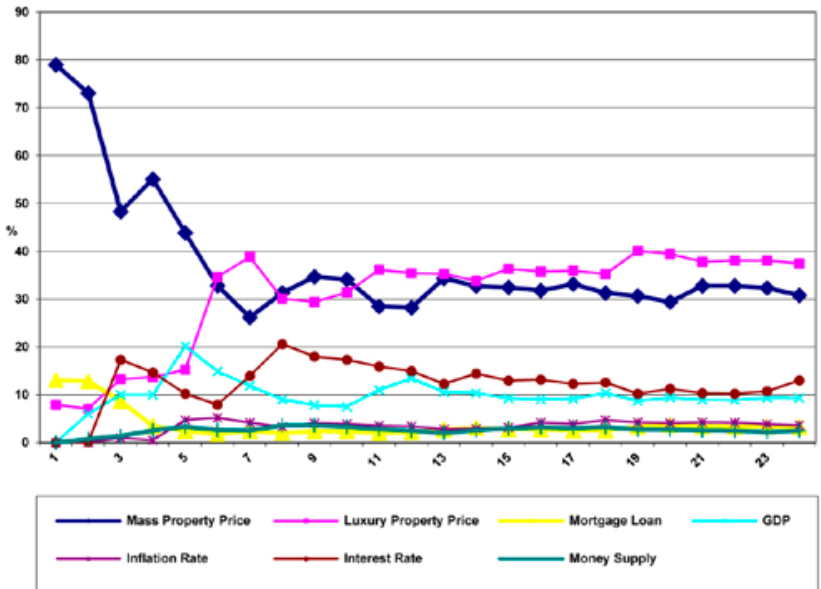

Fig. 9. Variance decomposition of outstanding residential loans

es in residential mortgage loans, the opposite is not found to be significant.

\section{CONCLUSIONS}

This study has investigated the relationship between bank lending and property price in Hong Kong's mass residential market and luxury residential market, as well as the relationship between property prices and various macroeconomic and monetary factors. Our findings suggest that, 1) property price in the mass residential market is subjected to shocks primarily from luxury housing price, GDP, inflation rate, and interest rate; 2 ) the luxury residential market is affected by shocks from GDP, interest rate, inflation rate, and particularly mass residential property price. Surprisingly, shocks in residential mortgage loans in Hong Kong do not incur a significant response from either the mass housing price or the luxury housing price. This is further confirmed as only oneway directional relationships are found, from mass residential property price to bank mortgage lending, from luxury property price to bank mortgage lending, as well as from mass residential property price to luxury residential property price. These relationships are in line with the results obtained in some previous studies (Gerlach, Peng 2003, 2005; Goodhart 1995; Goodhart, Hofmann 2003).

Based upon the findings, there are two implications worth discussing. The first implication concerns government's own housing-related policy initiatives. As shown in the findings, property price in the mass housing market has a one-way causal relationship with that in the luxury housing market. In other words, shocks in other macroeconomic and monetary factors not only could affect luxury prop- 
erty price directly, but also indirectly from prior adjustments in mass housing price. Yet, as such indirect impact(s) would be slightly lagged in nature, different dynamics (and subsequent government responses to them) on the two housing markets would be likely, even though they are subject to identical macroeconomic conditions. This implication might provide some directions as to how the government responds, with reference to housing-related policy initiatives, to market changes.

The second implication is related to the existing arrangement regarding the Hong Kong dollar (HKD). HKD has been pegged to the U.S. dollar (USD) since 1983. Currently, the linked exchange rate is at $1 \mathrm{USD}=7.8 \mathrm{HKD}$. Under this system, though having a relative stable currency, in order to maintain this pegged 1:7.8 rate, Hong Kong's market interest rate and money supply become highly susceptible to U.S. monetary policies. The numerous rounds of quantitative easing launched by the U.S. Federal Reserve, in attempt to rescue the stagnant U.S. economy, have led to much higher money supply within the U.S.; and, by association through the pegged exchange rate system, this inevitably affects the amount of money supply in Hong Kong, which in turn not only influences Hong Kong's economy directly in terms of GDP, interest rate and inflation rate through its one-directional causal relationships with them, but also indirectly affects Hong Kong's property markets via the one-directional relationships of GDP to both mortgage loans and luxury housing market. This might shed light on the study of other nations with similarly limited roles in deciding their money supply and interest rates due to their currencies being pegged with the U.S. Dollar (or Euro) under a fixed exchange rate system.

\section{ACKNOWLEDGEMENT}

The research was funded by the Hong Kong RCG (PolyU152059/14E:B-Q42Q) and the Polytechnic University's Internal Grants (G-UA6V and 4-ZZC8). The authors are grateful to the editor and anonymous reviewers for their help and comments.

\section{REFERENCE}

Ahearne, A.; Ammer, J.; Doyle, B.; Kole, L.; Martin, R. 2005. House prices and monetary policy: a crosscountry study, International Finance Discussion Papers 841. Board of Governors of the Federal Reserve System.
Aoki, K.; Proudman, J.; Vlieghe, G. 2004. House prices, consumption, and monetary policy: a financial accelerator approach, Journal of Financial Intermediation 13: 414-435. http://dx.doi.org/10.1016/j. jfi.2004.06.003

Barakova, I.; Bostic, R. W.; Calem, P. S.; Wachter, S. M. 2003. Does credit quality matter for homeownership, Journal of Housing Economics 12: 318-336. http:// dx.doi.org/10.1016/j.jfi.2004.06.003

Bernanke, B.; Gertler, M. 1995. Inside the blackbox: the credit channel of monetary policy transmission, Working Paper 5146. NBER.

BIS. 2001. Annual report 71st. Bank for International Settlements, Basel.

Collyns, C.; Senhadji, A. 2001. Lending booms, real estate bubbles and the Asian crisis, IMF Working $\mathrm{Pa}$ per No. 02/20, February 2002.

Davis, E.; Zhu, H. 2004. Bank lending and commercial property prices: some cross country evidence, BIS Working Paper No. 150.

De Greef, I. J. M.; de Haas, R. T. A. 2000. Housing prices, bank lending, and monetary policy, in The Financial Structure, Bank Behaviour and Monetary Policy in the EMU Conference, 5-6 October 2000, Groningen.

Fitzpatrick, T.; McQuinn, K. 2007. House prices and mortgage credit: empirical evidence for Ireland, The Manchester School 75(1): 82-103. http://dx.doi. org/10.1111/j.1467-9957.2007.01004.x

Gerlach, S.; Peng, W.; Shu, C. 2003. Macroeconomic conditions and banking performance in Hong Kong: a panel data study, in The Autumn Central Bank Economists' Meeting on Investigating the Relationship between the Financial and Real Economy, 9-10 October 2003, Bank for International Settlements.

Gerlach, S.; Peng, W. 2005. Bank lending and property prices in Hong Kong, Journal of Banking \& Finance 29: 461-481. http://dx.doi.org/10.1016/j.jbankfin.2004.05.015

Goodhart, C. 1995. Price stability and financial fragility, in Sawamoto, K.; Nakajima, Z.; Taguchi, H. (Eds.). Financial stability in a changing environment. Basingstoke: MacMillan. http://dx.doi.org/10.1007/978-1349-13352-9_11

Goodhart, C.; Hofmann, B. 2003. Deflation, credit and asset prices, HKIMR Working Paper No.13/2003.

Goodhart, C.; Hofmann, B. 2007. House prices and the macroeconomy: implications for banking and price stability. Oxford: Oxford University Press.

Hofmann, B. 2001. The determinants of private sector credit in industrialized countries: do property prices matter?, BIS Working Paper No. 108.

Hofmann, B. 2003. Bank lending and property prices: some international evidence, HKIMR Working Paper No.22/2003.

Hofmann, B. 2004. The determinants of bank credit in industrialized countries: do property prices matter?, International Finance 7(2): 203-234. http://dx.doi. org/10.1111/j.1367-0271.2004.00136.x

Iacoviello, M. 2004. Consumption, housing prices, and collateral constraints: a structural econometric analysis, Journal of Housing Economics 13: 304-320. http://dx.doi.org/10.1016/j.jhe.2004.09.004 
Iacoviello, M. 2005. House prices and borrowing constraints, monetary policy in the business cycle, American Economic Review 95: 739-764. http://dx.doi.org/10.1257/0002828054201477

IMF. 2000. World economic outlook, May 2000. IMF, Washington DC.

Jin, Y.; Zeng, Z. 2004. Residential investment and house prices in a multisector monetary business cycle model, Journal of Housing Economics 13: 268-286. http://dx.doi.org/10.1016/j.jhe.2004.08.001

Kim, K. 2004. Housing and the Korean economy, Journal of Housing Economics 13: 321-341. http://dx.doi. org/10.1016/j.jhe.2004.09.001

Kiyotaki, N.; Moore, J. 1997. Credit cycles, Journal of Political Economy 105: 211-248. http://dx.doi. org/10.1086/262072

Koh, W. T. H.; Mariano, R. S.; Pavlov, A.; Phang, S. Y.; Tan, A. H. H.; Wachter, S. M. 2005. Bank lending and real estate in Asia: market optimism and asset bubbles, Journal of Asian Economics 15: 1103-1118. http://dx.doi.org/10.1016/j.asieco.2004.11.004

Liang, Q.; Cao, H. 2007. Property prices and bank lending in China, Journal of Asian Economics 18: 63-75. http://dx.doi.org/10.1016/j.asieco.2006.12.013

Oikarinen, E. 2009. Interaction between housing prices and household borrowing: the Finnish case, Journal of Banking \& Finance 33: 747-756. http://dx.doi. org/10.1016/j.jbankfin.2008.11.004
Ortalo-Magné , F.; Rady, S. 2006. Housing market dynamics: on the contribution of income shocks and credit constraints, Review of Economic Studies 73: 459-485. http://dx.doi.org/10.1111/j.1467937X.2006.383_1.x

Park, S. W.; Bahug, D. W.; Park, Y. W. 2010. Price run-up in housing markets, access to bank lending and house prices in Korea, Journal of Real Estate Finance and Economics 40: 332-367. http://dx.doi. org/10.1007/s11146-008-9143-1

Sims, C. A.; Stock, J. H.; Watson, M. W. 1990. Inference in linear time series models with some unit roots, Econometrica 58: 113-144. http://dx.doi. org/10.2307/2938337

Stein, J. C. 1995. Prices and trading volume in the housing market: a model with down-payment effects, Quarterly Journal of Economics 110: 379-406. http://dx.doi.org/10.2307/2118444

Tsatsaronis, K.; Zhu, H. 2004. What drives housing price dynamics: cross-country evidence, BIS Quarterly Review (March 2004): 65-78.

Wheaton, W.; Negachev, G. 2006. Past housing cycles and the current housing boom: what's different this time?, Working Paper.

Yamashita, T. 2007. House price appreciation, liquidity constraints, and second mortgages, Journal of Urban Economics 62: 424-440. http://dx.doi.org/10.1016/j. jue.2006.11.003 